EETP Vol. 16, 2021, №. 2(60)

ISSN 1896-2327 / e-ISSN 2353-7787

DOI: 10.35765/eetp.2021.1660.04

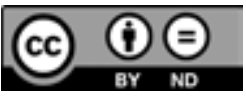

Nadesłano: 31.01 .2021

Zaakceptowano: 8.02.2021

Sugerowane cytowanie: Kamyk-Wawryszuk A. (2021). Niepełnosprawność rzadka jako kategoria nieobecna w kształceniu nauczycieli przedszkola i edukacji wczesnoszkolnej „Edukacja Elementarna w Teorii i Praktyce”, vol. 16, nr 2(60), s. 51-64.

DOI: 10.35765/eetp.2021.1660.04

\author{
Agnieszka Kamyk-Wawryszuk \\ ORCID: 0000-0002-0545-6416 \\ Uniwersytet Kazimierza Wielkiego w Bydgoszczy
}

\title{
Niepełnosprawność rzadka jako kategoria nieobecna w kształceniu nauczycieli przedszkola i edukacji wczesnoszkolnej
}

\section{Rare Disability as an Absent Category in Educating Pre-School and Early School Teachers}

\begin{abstract}
SŁOWA KLUCZE ABSTRAKT
niepełnosprawność

rzadka, nauczyciel, edukacja przedszkolna i wczesnoszkolna, programy kształcenia, kształcenie uniwersyteckie

Niepełnosprawność rzadka jest szerszym pojęciem niż niepełnosprawność sprzężona i uwzględnia wszystkie rodzaje niepełnosprawności. Jest związana ze zdiagnozowaniem choroby rzadkiej. W ostatnim dziesięcioleciu można zaobserwować wzrost liczby dzieci z RD, które uczestniczą w terapii i edukacji. Stąd istotne jest omawianie zagadnień związanych z niepełnosprawnością rzadką na zajęciach dla studentów pedagogiki przedszkolnej i wczesnoszkolnej. Celem podjętych badań była analiza programów kształcenia na kierunku pedagogika przedszkolna i wczesnoszkolna w kontekście realizowanych treści z zakresu problematyki niepełnosprawności, w tym rzadkiej, oraz wskazanie w nich przestrzeni, gdzie może być omawiana. Za główną metodę badawczą obrano analizę danych wtórnych (desk-research). Analizie poddano 7 programów ( 5 uniwersytetów, 2 akademie). Na podstawie przeprowadzonych badań można stwierdzić, że studenci mają realizowane w ramach studiów treści dotyczące przedszkolaków i uczniów ze zdiagnozowaną niepełnosprawnością intelektualną lub sprzężoną. Dodatkowo poruszane są zagadnienia niepełnosprawności wzrokowej, słuchowej i ruchowej. Na żadnych zajęciach nie była poruszana problematyka niepełnosprawności rzadkiej.
\end{abstract}




\section{KEYWORDS ABSTRACT}

rare disease, teacher, pre-school and early school education, teaching curricula, university education
A rare disability $(\mathrm{RD})$ is a concept that is much broader than multiple disabilities; a rare disability includes all kinds of disabilities. A rare disability is connected with the medical diagnosis of a rare disease. In the last decade, an increase in the number of children with RD, who participate in therapies and education, is noticeable. Thus, it is important for pre-school and early school education students to learn about various issues connected with rare disabilities. The main goal of the research carried out by the author of the article was the analysis of teaching curricula of the universities who teach pre-school and early school teachers in the context of disabilities, including rare ones. The main method of analysis was desk-research. Seven curricula were analysed (five universities and two academies). Based on the results, it may be concluded that students study various issues related to preschoolers and early school children with diagnosed intellectual or multiple disabilities. Additionally, some other aspects of disabilities are brought up, e.g. visual, hearing or/and motor impairment. On the other hand, none of the analysed curricula included issues related to rare disabilities.

\section{Wprowadzenie}

Nauczyciel pracujący z dziećmi w grupie przedszkolnej, jak i z uczniami klas I-III, jest często pierwszym specjalistą z zakresu rozwoju dziecka, który dostrzega trudności w jego funkcjonowaniu. Zdarza się, że to właśnie z inicjatywy nauczyciela jego wychowanek jest kierowany na dalsze badania pedagogiczne czy psychologiczne umożliwiające sporządzenie diagnozy funkcjonalnej. Dlatego w edukacji przyszłych pedagogów istotne jest uwzględnienie treści z zakresu pedagogiki specjalnej, w tym charakterystyki wybranych rodzajów niepełnosprawności. Choroba rzadka (rare disease, $\mathrm{RD}$ ), którą diagnozuje się u 2 na 10000 osób (Komisja Wspólnot Europejskich 2008: 2) może uwidocznić się w różnym wieku. Niektóre z jej rodzajów mogą nie ujawniać się do trzeciego, a nawet piątego roku życia. Dziecko rozwija się w tym czasie prawidłowo. Dopiero wraz z upływemh lat można dostrzec stopniowe opóźnienie w jego rozwoju. Jest to etap edukacji przedszkolnej; czasem te zmiany w funkcjonowania dziewczynki/ chłopca są dostrzegalne później, podczas nauki w klasie pierwszej szkoły podstawowej. Niepełnosprawność rzadka postrzegana jako efekt RD, często jest pomijana i niedostrzegana w obszarze pedagogiki specjalnej. Wynika to z dwóch przesłanek. Pierwsza to mała liczba osób z taką diagnozą, co przekłada się często na badania o charakterze kazuistycznym, a nie ilościowym. Druga to tak zwany indywidualny obraz choroby rzadkiej. Oznacza on, że dwoje dzieci z tą samą diagnozą może mieć częściowo te same 
symptomy, ale ich funkcjonowanie motoryczne, emocjonalne i społeczne będzie inne. Czasem wskazuje się na niejednorodny wzorzec rozwojowy. Mniejsza liczba publikacji poruszających problematykę RD może przekładać się na okazjonalne dyskusje nad pojęciem niepełnosprawności rzadkiej.

\section{Niepełnosprawność rzadka - dyskusja wokół terminu}

Istnieje wiele definicji niepełnosprawności podkreślających ograniczenia na tle somatycznym, psychicznym czy społecznym (Chrzanowska 2015). W rozważaniach na temat niepełnosprawności rzadkiej przyjęłam za Aleksandrem Hulkiem, że niepełnosprawność to „stan fizyczny bądź psychiczny trwale lub chociażby okresowo utrudniający, ograniczający albo całkowicie uniemożliwiający wypełnianie zadań życiowych oraz ról społecznych zgodnie z obowiązującymi w tym zakresie normami społecznymi, jak i regulacjami prawnymi” (Hulek 1992: 24). Wybór definicji jest podyktowany kilkoma ważnymi czynnikami. Po pierwsze, odnosi się ona do zaburzeń w obrębie stanu somatycznego, co najczęściej pojawia się w przypadku chorób rzadkich. Po drugie, nie zawsze $\mathrm{RD}$ wiąże się z trwałymi ograniczeniami w wypełnianiu zadań życiowych. Niektóre z nich powodują okresowe utrudnienia, gdy jest nasilenie symptomów i pojawia się potrzeba hospitalizacji. Jednocześnie podkreśla też „drugą twarz” chorób rzadkich, która pokazuje, że aż około 30\% dzieci z taką diagnozą umiera przed skończeniem 5. roku życia (Sangiorgi, Mordenti 2017: 145). Zatem RD może mieć charakter stabilny, jak i progresywny. W literaturze można także znaleźć informacje, że istnieje trudność co do zdefiniowania terminu „niepełnosprawność rzadka”. Na przykład pojęcie to nie istnieje w systemie orzecznictwa o stopniu niepełnosprawności (Kulik, Wiącek, 2010: 100), a w ramach niego najczęściej pojawia się w przypadku osób ze zdiagnozowaną RD niepełnosprawność sprzężona. W dyskusjach o niepełnosprawności można dostrzec, że nie włącza się chorób rzadkich jako jednego z czynników, który może ją wywołać. Niektórzy badacze wskazują nawet na zjawisko maskowania „chorób rzadkich jako możliwego źródła niepełnosprawności" (Wiszejko-Wierzbicka i in. 2010: 198). Jednak należy w tym miejscu podkreślić, że nie każda choroba rzadka prowadzi do niepełnosprawności. Zatem może być następująca sytuacja, że dana osoba ma zdiagnozowaną $\mathrm{RD}$ i:

a) nie ma żadnej niepełnosprawności,

b) zdiagnozowano u niej dany rodzaj niepełnosprawności, np. jest osobą poruszającą się na wózku inwalidzkim,

c) ma niepełnosprawność sprzężoną, np. niepełnosprawność intelektualna i poważna wada wzroku,

d) niepełnosprawność rzadką (Wiszejko-Wierzbicka i in. 2010: 198). 
Jak podkreśla Joanna Urbańska,

(...) pojęcie niepełnosprawności rzadkiej można zdefiniować jako taki rodzaj niepełnosprawności, która sporadycznie występuje w danej populacji i najczęściej dotyczy osób cierpiących na bardzo rzadkie choroby. Szacuje się, że w $80 \%$ choroby doprowadzające do rzadkiej niepełnosprawności mają podłoże genetyczne. Niepełnosprawność rzadka może też wystąpić w konsekwencji urazu powypadkowego lub okołoporodowego oraz być następstwem częstej choroby o niestandardowym przebiegu" (Urbańska 2010: 120-121).

Na podstawie analizy literatury, uczestnictwa w konferencjach, gdzie podejmowano szeroko zagadnienie ograniczeń w funkcjonowaniu wynikających ze zdiagnozowania choroby rzadkiej, jak i kilkuletniej współpracy z rodzicami i terapeutami dzieci z chorobą rzadką, można dostrzec, że niepełnosprawność rzadka:

odnosi się do zdiagnozowania choroby rzadkiej, w skutek której pojawia się czasowe lub trwałe ograniczenie w funkcjonowaniu i wykonywaniu ról życiowych i społecznych,

- dotyczy małej liczby osób, zarówno dzieci, jak i dorosłych,

- obejmuje swoim zakresem wszystkie rodzaje niepełnosprawności,

- wymaga spersonalizowanej ścieżki terapeutycznej uwzględniającej zmienność samopoczucia danej osoby, zróżnicowane etapy choroby, specyfikę leczenia realizowanego często poza granicami państwa,

- wymaga innej formy wsparcia społecznego w ujęciu strukturalnym i funkcjonalnym.

Wprowadzenie tego terminu jest swoistego rodzaju przełożeniem perspektywy medycznej, w której centrum zainteresowania są poszczególne choroby rzadkie, na perspektywę terapeutyczną, która między innymi koncentruje się na pracy z osobami z niepełnosprawnością, w tym przypadku rzadką. Pozwala to na ograniczenie procesu medykalizacji w pedagogice specjalnej.

\section{Kształcenie na kierunku pedagogika przedszkolna i wczesnoszkolna w Polsce}

Zgodnie z obowiązującymi w Polsce przepisami, od pierwszego października 2019 roku uczelnie wyższe mogły rozpocząć kształcenie na jednolitych studiach magisterskich kierunku pedagogika przedszkolna i wczesnoszkolna. Studia te przygotowują do pracy nauczyciela przedszkola oraz klas I-III. Kształcenie obejmuje zarówno przygotowanie merytoryczne, jak i pedagogiczne. W ramach przygotowania pedagogicznego uczestnicy studiów realizują zajęcia z zakresu przygotowania 
psychologiczno-pedagogicznego i dydaktycznego. Jednocześnie studenci w toku studiów powinni mieć w programie grupy zajęć, które poruszają zagadnienie funkcjonowania dzieci z trudnościami w rozwoju, takie jak:

- Dziecko lub uczeń ze specjalnymi potrzebami rozwojowymi i edukacyjnymi w przedszkolu i klasach I-III szkoły podstawowej,

Organizacja pracy przedszkola i szkoły z elementami prawa oświatowego i praw dziecka oraz kultura przedszkola i szkoły, w tym w zakresie kształcenia uczniów ze specjalnymi potrzebami edukacyjnymi i niepełnosprawnościami (Dz.U. 2019 poz. 1450).

Zatem przewidziano przestrzeń na omówienie rodzajów niepełnosprawności, trudności, jakich doświadczają dzieci z taką diagnozą, oraz możliwości ich edukacji i terapii.

Wskazana problematyka została ujęta w ogólnych efektach kształcenia do zawodu nauczyciela przedszkola i edukacji wczesnoszkolnej (tabela 1).

Tabela 1. Efekty kształcenia na kierunku pedagogika przedszkolna i wczesnoszkolna związane z problematyką niepełnosprawności

\begin{tabular}{|c|c|c|}
\hline \multicolumn{3}{|c|}{ Absolwent zna/rozumie/potrafi/ jest gotów w zakresie } \\
\hline Wiedzy & Umiejętności & Kompetencji społecznych \\
\hline $\begin{array}{l}\text { - } \text { zagadnienie edukacji } \\
\text { włączającej, a także sposoby } \\
\text { realizacji zasady inkluzji; } \\
\text { prawa dziecka i osoby } \\
\text { z niepełnosprawnością, } \\
\text { sposoby ich egzekwowania } \\
\text { oraz propagowania } \\
\text { w środowisku zarówno } \\
\text { przedszkolnym } \\
\text { oraz szkolnym, jak } \\
\text { i pozaprzedszkolnym oraz } \\
\text { pozaszkolnym; }\end{array}$ & $\begin{array}{l}\text { rozpoznawać potrzeby, } \\
\text { możliwości i uzdolnienia } \\
\text { dzieci lub uczniów oraz } \\
\text { projektować i prowadzić } \\
\text { działania pedagogiczne, } \\
\text { a także planować, realizować } \\
\text { i oceniać spersonalizowane } \\
\text { programy kształcenia } \\
\text { i wychowania; } \\
\text { wykorzystywać w codziennej } \\
\text { praktyce edukacyjnej } \\
\text { różnorodne sposoby } \\
\text { organizowania środowiska } \\
\text { uczenia się i nauczania, } \\
\text { z uwzględnieniem } \\
\text { specyficznych potrzeb } \\
\text { i możliwości poszczególnych } \\
\text { dzieci lub uczniów oraz } \\
\text { grupy; }\end{array}$ & $\begin{array}{l}\text { pracy w zespole, } \\
\text { pełnienia w nim różnych } \\
\text { ról oraz współpracy } \\
\text { z nauczycielami, } \\
\text { pedagogami, } \\
\text { specjalistami, rodzicami } \\
\text { lub opiekunami dzieci } \\
\text { lub uczniów i innymi } \\
\text { członkami społeczności } \\
\text { przedszkolnej, szkolnej } \\
\text { i lokalnej }\end{array}$ \\
\hline
\end{tabular}




\begin{tabular}{|c|c|c|}
\hline \multicolumn{3}{|c|}{ Absolwent zna/rozumie/potrafi/ jest gotów w zakresie } \\
\hline Wiedzy & Umiejętności & Kompetencji społecznych \\
\hline $\begin{array}{l}\text { - zróżnicowane potrzeby } \\
\text { rozwojowe i edukacyjne } \\
\text { dzieci lub uczniów w okresie } \\
\text { przedszkolnym i młodszym } \\
\text { wieku szkolnym, wynikające } \\
\text { z opóźnień, zaburzeń lub } \\
\text { przyspieszenia rozwoju, oraz } \\
\text { uwarunkowane wpływem } \\
\text { czynników środowiskowych } \\
\text { i sposoby dostosowywania } \\
\text { do nich zadań rozwojowych } \\
\text { i edukacyjnych; } \\
\text { projektowanie i prowadzenie } \\
\text { działań diagnostycznych } \\
\text { uwzględniających specyfikę } \\
\text { funkcjonowania dzieci } \\
\text { w wieku przedszkolnym } \\
\text { i młodszym wieku szkolnym } \\
\text { oraz ich zróżnicowane } \\
\text { potrzeby edukacyjne, w tym } \\
\text { zakres i jakość wsparcia } \\
\text { społecznego; } \\
\text { funkcjonowanie i dysfunkcje } \\
\text { aparatu mowy, słuchu } \\
\text { i wzroku oraz prawidłowe } \\
\text { nawyki posługiwania się nimi }\end{array}$ & $\begin{array}{l}\text { skutecznie wykorzystywać } \\
\text { w pracy z dzieckiem } \\
\text { lub uczniem informacje } \\
\text { uzyskane na jego temat } \\
\text { od specjalistów, w tym } \\
\text { psychologa, logopedy, } \\
\text { pedagoga, lekarza, i rodziców } \\
\text { lub opiekunów dziecka lub } \\
\text { ucznia }\end{array}$ & \\
\hline
\end{tabular}

Źródło: Rozporządzenie Ministra Nauki i Szkolnictwa Wyższego z dnia 25 lipca 2019 r. w sprawie standardu kształcenia przygotowującego do wykonywania zawodu nauczyciela, Dz.U. 2019 poz. 1450

W obecnie obowiązujących przepisach prawnych dotyczących standardów kształcenia nauczycieli przedszkola i edukacji wczesnoszkolnej ustawodawca uwzględnił w procesie edukacyjnym problematykę funkcjonowania dzieci ze specjalnymi potrzebami edukacyjnymi i z niepełnosprawnością.

\section{Metodologia badań własnych}

Głównym celem podjętych badań była analiza programów kształcenia na kierunkach pedagogiki przedszkolnej i wczesnoszkolnej w kontekście realizowanych treści z zakresu problematyki niepełnosprawności, w tym rzadkiej, oraz wskazanie w nich przestrzeni, gdzie może ona być omawiana. $Z$ tego też względu za główną metodę 
badawczą przyjęłam analizę danych wtórnych desk-research. Jak podkreśla Dariusz Kubinowski, dokumentacja różnego rodzaju jest ważnym i użytecznym źródłem w badaniach osadzonych w strategii jakościowej. Wśród powodów, jakie decydują o tego typu badaniu, badacz wymienia powszechność ich dostępu, trwałość oraz bogactwo zasobów informacji istotnych w kontekstach, których dotyczy zarówno jego treść, jak i forma (Kubinowski 2011:214). W procesie badawczym wzięłam pod uwagę źródła wtórne, takie jak zapisy publiczne, przede wszystkim oficjalne dokumenty, jakimi są programy kształcenia. Podjęte badania podzieliłam na trzy etapy. Pierwszy to sporządzenie listy szkół wyższych, które mają w swojej ofercie dla absolwentów szkół średnich kierunek pedagogika przedszkolna i wczesnoszkolna; wyłonienie z tego zbioru tych, które realizują ten kierunek w systemie jednolitym magisterskim, stacjonarnym. Drugi etap to wyszukiwanie na oficjalnych stronach uczelni, które realizują kształcenie na kierunku pedagogika przedszkolna i wczesnoszkolna, dokumentów (programów kształcenia), trzeci to ich krytyczna analiza pod kątem słów kluczowych, takich jak niepełnosprawność rzadka, dziecko ze zdiagnozowaną chorobą rzadką, choroba rzadka.

Zatem analizie poddano programy kształcenia na kierunku pedagogika przedszkolna i wczesnoszkolna, studia jednolite magisterskie, bez specjalności, stacjonarne realizowane na wybranych siedmiu uczelniach wyższych w Polsce: Uniwersytet Warszawski, Uniwersytet Jagielloński, Uniwersytet Pedagogiczny w Krakowie, Uniwersytet Śląski w Katowicach, Uniwersytet Warmińsko-Mazurski w Olsztynie, Akademia Pedagogiki Specjalnej im. M. Grzegorzewskiej w Warszawie, Akademia Marynarki Wojennej w Gdyni. Łącznie analizie poddano dokumenty z pięciu uniwersytetów i dwóch akademii. Każdej uczelni nadano kod, uniwersytetom DW_U, zaś akademiom DW_A oraz cyfry od 1 do 5, aby uporządkować kolejność analizowanych dokumentów. I tak np. kod DW_U1 oznacza dokumenty wtórne uniwersytet, program pierwszy.

Celem prowadzonych badań nie było pokazanie braków w istniejących programach kształcenia, a wskazanie przestrzeni, w ramach której mogą zaistnieć zagadnienia związane z niepełnosprawnością rzadką.

Sformułowałam następujące główne pytanie badawcze: czy programy kształcenia na kierunku pedagogika przedszkolna i wczesnoszkolna zawierają treści dotyczące niepełnosprawności rzadkiej?

oraz pytania szczegółowe:

- na jakich modułach zajęć poruszane są zagadnienia dotyczące niepełnosprawności?

- na jakich przedmiotach studenci realizują treści programowe związane z charakterystyką i funkcjonowaniem dzieci z niepełnosprawnością?

z jakimi rodzajami niepełnosprawności są zapoznawani studenci w ramach przedmiotów realizujących treści z zakresu niepełnosprawności? 


\section{Programy kszłałcenia na kierunku pedagogika przedszkolna i wczesnoszkolna a zagadnienie niepełnosprawności rzadkiej}

W programach jednolitych studiów magisterskich na kierunku pedagogika przedszkolna i wczesnoszkolna można znaleźć efekty kształcenia, w ramach których mogła by być poruszana problematyka niepełnosprawności rzadkiej (tabela 1).

Tabela 1. Wybrane efekty kształcenia poruszające problematykę niepełnosprawności

\begin{tabular}{|c|c|c|}
\hline \multicolumn{3}{|c|}{ Absolwent zna/potrafi/jest } \\
\hline Wiedza & Umiejętności & Kompetencje społeczne \\
\hline $\begin{array}{l}\text { prawa dziecka i osoby } \\
\text { z niepełnosprawnością, } \\
\text { sposoby ich egzekwowania } \\
\text { oraz propagowania } \\
\text { w środowisku zarówno } \\
\text { przedszkolnym } \\
\text { oraz szkolnym, jak } \\
\text { i pozaprzedszkolnym oraz } \\
\text { pozaszkolnym }\end{array}$ & $\begin{array}{l}\text { - skutecznie wykorzystywać } \\
\text { w pracy z dzieckiem } \\
\text { lub uczniem informacje } \\
\text { uzyskane na jego temat } \\
\text { od specjalistów, w tym } \\
\text { psychologa, logopedy, } \\
\text { pedagoga, lekarza i rodziców } \\
\text { lub opiekunów dziecka lub } \\
\text { ucznia }\end{array}$ & $\begin{array}{l}\text { - potrafi realizować } \\
\text { innowacje pedagogiczne } \\
\text { związane z wyzwaniami } \\
\text { społecznymi } \\
\text { i cywilizacyjnymi } \\
\text { przyszłości, służące } \\
\text { rozwojowi uczniów } \\
\text { oraz integracji rodziców } \\
\text { i środowiska lokalnego } \\
\text { z instytucją edukacyjną }\end{array}$ \\
\hline $\begin{array}{l}\text { zróżnicowane potrzeby } \\
\text { rozwojowe i edukacyjne } \\
\text { dzieci lub uczniów w okresie } \\
\text { przedszkolnym i młodszym } \\
\text { wieku szkolnym, wynikające } \\
\text { z opóźnień, zaburzeń lub } \\
\text { przyspieszenia rozwoju, oraz } \\
\text { uwarunkowane wpływem } \\
\text { czynników środowiskowych } \\
\text { i sposoby dostosowywania } \\
\text { do nich zadań rozwojowych } \\
\text { i edukacyjnych }\end{array}$ & $\begin{array}{l}\text { - wykorzystywać w codziennej } \\
\text { praktyce edukacyjnej } \\
\text { różnorodne sposoby } \\
\text { organizowania środowiska } \\
\text { uczenia się i nauczania, } \\
\text { z uwzględnieniem } \\
\text { specyficznych potrzeb } \\
\text { i możliwości poszczególnych } \\
\text { dzieci lub uczniów oraz } \\
\text { grupy }\end{array}$ & $\begin{array}{l}\text { - jest gotowy do } \\
\text { prowadzenia } \\
\text { zindywidualizowanych } \\
\text { działań pedagogicznych } \\
\text { (dydaktycznych, } \\
\text { wychowawczych } \\
\text { i opiekuńczych) } \\
\text { w stosunku do } \\
\text { uczniów ze specjalnymi } \\
\text { potrzebami } \\
\text { edukacyjnymi }\end{array}$ \\
\hline $\begin{array}{l}\text { - funkcjonowanie i dysfunkcje } \\
\text { aparatu mowy, słuchu } \\
\text { i wzroku oraz prawidłowe } \\
\text { nawyki posługiwania się nimi }\end{array}$ & $\begin{array}{l}\text { - diagnozować dzieci/ } \\
\text { uczniów z zaburzeniami } \\
\text { w różnych sferach rozwoju } \\
\text { oraz dostosować programy } \\
\text { dydaktyczne, wychowawcze } \\
\text { i profilaktyczne do } \\
\text { aktualnych potrzeb } \\
\text { indywidualnych i grupowych }\end{array}$ & $\begin{array}{l}\text { - posiada świadomość } \\
\text { idei holistycznego } \\
\text { podejścia do jednostki } \\
\text { z różnego typu } \\
\text { niepełnosprawnościami }\end{array}$ \\
\hline
\end{tabular}




\begin{tabular}{|c|c|c|}
\hline \multicolumn{3}{|c|}{ Absolwent zna/potrafi/jest } \\
\hline Wiedza & Umiejętności & Kompetencje społeczne \\
\hline & $\begin{array}{l}\text { posługiwać się wiedzą } \\
\text { teoretyczną z zakresu } \\
\text { pedagogiki, psychologii } \\
\text { oraz dydaktyki i metodyki } \\
\text { szczegółowej w celu } \\
\text { diagnozowania, analizowania } \\
\text { i prognozowania sytuacji } \\
\text { pedagogicznych oraz } \\
\text { dobierania strategii } \\
\text { realizowania działań } \\
\text { praktycznych na } \\
\text { poszczególnych etapach } \\
\text { edukacyjnych oraz } \\
\text { identyfikować spontaniczne } \\
\text { zachowania dzieci lub } \\
\text { uczniów jako sytuacje } \\
\text { wychowawczo-dydaktyczne } \\
\text { i wykorzystywać je } \\
\text { w procesie edukacji } \\
\text { oraz realizacji celów } \\
\text { terapeutycznych }\end{array}$ & $\begin{array}{l}\text { posiada przekonanie } \\
\text { o wartości } \\
\text { włączenia osób } \\
\text { z niepełnosprawnością } \\
\text { w główny nurt życia } \\
\text { społecznego }\end{array}$ \\
\hline
\end{tabular}

Źródło: opracowanie własne na podstawie dostępnych programów kształcenia na kierunku pedagogika przedszkolna i wczesnoszkolna, studia jednolite magisterskie, rozpoczęcie cyklu kształcenia 2020/2021

Uwzględniają one charakterystyczne cechy funkcjonowania dzieci z trudnościami w rozwoju. Wspomniane efekty są przypisane do przedmiotów, które zawierają treści dotyczące niepełnosprawności i są pogrupowane w moduły. Na podstawie analizy programów kształcenia i programów studiów wybranych uczelni można wspomniane moduły podzielić według trzech kategorii. Pierwsza związana jest z funkcjonowaniem dziecka w przestrzeni przedszkolnej i szkolnej. Druga to zagadnienia odnoszące się do inkluzji; trzecia to wspomaganie rozwoju dziecka oraz jego specjalne potrzeby edukacyjne. Wyjątek stanowi jedna akademia (DW_A1), która w programie już w module ogólnym zawarła przedmiot „Psychospołeczne aspekty niepełnosprawności”. W tym przypadku realizowane są zagadnienia: modelu niepełnosprawności, procesu stawania się osobą z niepełnosprawnością i jej sytuacja psychologiczna. Brakuje dookreślenia, jakiego rodzaju niepełnosprawności dotyczy.

Na przykład na drugim roku studiów problematyka niepełnosprawności jest poruszana na module „Dziecko w przedszkolu i szkole”, w ramach przedmiotów: Edukacja w przedszkolu, Psychologia edukacyjna, Podstawy diagnozy i monitorowania w pracy 
pedagoga. W ich toku są realizowane treści odnoszące się do koncepcji i modeli specjalnych potrzeb rozwojowych i edukacyjnych dzieci z:

nadpobudliwością psychoruchową,

ryzykiem dysleksji,

spektrum autyzmu,

niepełnosprawnością intelektualną,

- mózgowym porażeniem dziecięcym,

- chorobą przewlekłą i zaburzeniami o podłożu genetycznym (DW_U1).

Zatem studenci są zapoznawani z funkcjonowaniem dziecka z niepełnosprawnością, w szczególności z niepełnosprawnością intelektualną. Brakuje treści odnoszących się do niepełnosprawności rzadkiej, której problematyka mogłaby być realizowana w ramach wspomnianych zaburzeń o podłożu genetycznym, chorób przewlekłych i odmienności somatycznych.

Na piątym roku studenci w zakresie modułu „Nauczyciel w przedszkolu i w szkole" w ramach przedmiotów: Elementy prawa dla nauczycieli, Dokumentowanie i ewaluacja działań dydaktyczno-wychowawczych w przedszkolu i szkole, realizują następujące treści nawiązujące do problematyki niepełnosprawności:

prawa dzieci i osób z niepełnosprawnością w szkole,

zasady tworzenia projektów edukacyjnych, programów autorskich,

- współpraca z rodzicami dziecka, specjalistami, w celu włączenia ich w działania podnoszące efektywność edukacji (DW_U1).

$\mathrm{Na}$ jednym z uniwersytetów (DW_U2) przedmioty poruszające problematykę niepełnosprawności są realizowane nie w ramach modułu, ale w bloku przedmiotów obowiązkowych. Przykładem jest przedmiot „Prawa dziecka i prawa osób z niepełnosprawnościami”, w ramach którego omawiane są prawa osób z niepełnosprawnościami w przedszkolu i szkole. Drugim przedmiotem jest „Integracja w edukacji przedszkolnej i wczesnoszkolnej”, podczas którego student zapoznaje się z pojęciem integracji i inkluzji, a także projektuje działania wobec dzieci z niepełnosprawnością fizyczną i intelektualną w szkole ogólnodostępnej oraz innej wymagającej wsparcia integracyjnego. $\mathrm{Na}$ innym uniwersytecie te same zagadnienia są realizowane w ramach przedmiotu „Modele i strategie edukacji zintegrowanej” (DW_U5).

Innym przedmiotem, podczas którego realizowane są treści dotyczące niepełnosprawności sprzężonej, są „Elementy logopedii z reedukacją”. Uczestnicy tych zajęć poznają: „medyczne podstawy logopedii; biologiczne podstawy mowy i myślenia; anatomię i fizjologię układu nerwowego; podstawy audiologii i foniatrii; zaburzenia głosu; zaburzenia genetyczne i niepełnosprawności sprzężone”. Natomiast na zajęciach z „Podstaw edukacji zdrowotnej” studenci są zapoznawani z edukacją zdrowotną dzieci z chorobami przewlekłymi i niepełnosprawnością intelektualną (DW_U2). 
Na jednym z uniwersytetów (DW_U3) studenci w ramach realizacji zajęć na kierunku mogą wybrać blok fakultatywny „Ekspert od wspierania rozwoju”, w ramach którego realizują treści niezbędne w pracy z dziećmi z niepełnosprawnością. Student ma możliwość zdobycia wiedzy z zakresu:

- wspierania rozwoju dziecka,

- funkcjonowania wychowanka, określając jego zasoby i deficyty,

- planowania i realizacji procesu dydaktyczno-wychowawczego, który wzmacniać będzie autonomię i samostanowienie dziecka.

Te treści są także omawiane na przedmiocie „Strategie wspierania rozwoju ucznia w edukacji zintegrowanej" (DW_U5). Nie ma jednak w opisie modułu określonego typu niepełnosprawności, ale zaakcentowane są trudności, jakich mogą doświadczać wychowankowie. Jest to kolejny moduł, w ramach którego można by realizować także treści z zakresu niepełnosprawności rzadkiej. Odpowiednikiem przedmiotu „Ekspert od wspierania rozwoju”, realizowanego na uniwersytecie, są na akademii „Metody wspomagania rozwoju dziecka” (DW_A1).

Zagadnienie niepełnosprawności jest także poruszane na przedmiotach dotyczących specjalnych potrzeb edukacyjnych. Na przykład na uniwersytecie (DW_U5) jest realizowany przedmiot Specjalne potrzeby edukacyjne dzieci, zaś na akademii (DW_ A2) blok Dziecko lub uczeń ze specjalnymi potrzebami rozwojowymi i edukacyjnymi w przedszkolu i klasach I-III szkoły, Wspieranie rozwoju dzieci w wieku przedszkolnym i młodszym wieku szkolnym, lub Organizacja pracy przedszkola i szkoły z elementami prawa oświatowego i praw dziecka oraz kultura przedszkola i szkoły, w tym w zakresie kształcenia uczniów ze specjalnymi potrzebami edukacyjnymi. W skład pierwszego wchodzą następujące przedmioty: Zaburzenia i dysharmonie rozwojowe, Edukacja włączająca, czy Konstruowanie indywidualnych programów dydaktycznych dla uczniów o specjalnych potrzebach edukacyjnych. Natomiast drugi tworzą: Pierwsza pomoc i ratownictwo przedmedyczne, Struktura i funkcje systemu oświaty, Prawne podstawy oświaty i wychowania, czy Kultura i jakość pracy przedszkola i szkoły.

Podsumowując przeprowadzoną analizę modułów i wchodzących w ich skład przedmiotów pod względem proponowanych treści kształcenia, zauważalny jest fakt, że pomijany jest w programach studiów przedmiot Pedagogika specjalna. Jest on realizowany tylko na trzech z pięciu uczelni (pedagogika specjalna DW_U3, DW_U4, podstawy pedagogiki specjalnej DW_U2) i na żadnej z akademii. W ramach tego przedmiotu studenci zaznajamiają się z:

zagadnieniami z zakresu niepełnosprawności słuchowej, wzrokowej, intelektualnej oraz specyfiki rozwoju i społecznego funkcjonowania tych osób, formami i metodami wspomagania rozwoju osób z różnym rodzajem dysfunkcji rozwojowej (DW_U4), 
- diagnozą kliniczno-psychologiczną niepełnosprawności intelektualnej, słuchowej, wzrokowej i ruchowej (DW_U2),

- niepełnosprawnością intelektualną, słuchową, wzrokową, ruchową w różnych fazach życia jednostki (DW_U2),

- współczesnymi systemami rewalidacji osób niepełnosprawnych, formami postępowania terapeutyczno-wychowawczego i rehabilitacyjnego w poszczególnych rodzajach niepełnosprawności (DW_U2),

- pracą w różnych środowiskach wychowawczych na rzecz osób z niepełnosprawnością (DW_U3).

Zatem można stwierdzić, że studenci w ramach przedmiotu Pedagogika specjalna zdobywają wiedzę niezbędną do podejmowania zagadnień z zakresu niepełnosprawności sprzężonej. W żadnym z programów nie znalazły się takie pojęcia jak: dziecko ze zdiagnozowaną chorobą rzadką, czy choroba rzadka.

\section{Podsumowanie i wnioski}

Problematyka funkcjonowania dzieci ze zdiagnozowaną chorobą rzadką, co za tym idzie także niepełnosprawność rzadka, coraz częściej staje się przedmiotem zainteresowań badaczy. $\mathrm{Na}$ przestrzeni ostatnich 20 lat było to zagadnienie przede wszystkim badane przez lekarzy. Wynikało to z faktu, iż niejednokrotnie było to nowe zjawisko medyczne, zatem brakowało chociażby standardów leczenia i rehabilitacji. Nadal mamy wielką grupę chorób, których nie można leczyć, a stosuje się wyłącznie różnego rodzaju środki zachowawcze. Jednak grupa dzieci z rozpoznaną RD - między innymi dzięki postępowi medycyny - zwiększa się. Zatem istnieje potrzeba poruszania tego tematu wśród pedagogów, w tym przedszkolnych i wczesnoszkolnych.

$\mathrm{Na}$ podstawie przeprowadzonych badań można wskazać, że zakładane efekty kształcenia w każdym z analizowanych programów umożliwiają realizację na poszczególnych przedmiotach treści odnoszących się do niepełnosprawności rzadkiej.

Treści dotyczące charakterystyki funkcjonowania dzieci ze zdiagnozowaną niepełnosprawnością są realizowane na następujących modułach:

- Dziecko w przedszkolu i szkole,

- Nauczyciel w przedszkolu i w szkole,

- Dziecko lub uczeń ze specjalnymi potrzebami rozwojowymi i edukacyjnymi w przedszkolu i klasach I-III szkoły,

Wspieranie rozwoju dzieci w wieku przedszkolnym i młodszym wieku szkolnym,

- Ekspert od wspierania rozwoju, 
- Organizacja pracy przedszkola i szkoły z elementami prawa oświatowego i praw dziecka oraz Kultura przedszkola i szkoły, w tym w zakresie kształcenia uczniów ze specjalnymi potrzebami edukacyjnymi.

Moduły te prezentują treści dotyczące przedszkolaków i uczniów ze zdiagnozowaną niepełnosprawnością intelektualną lub sprzężoną. Na jednym tylko przedmiocie (pedagogika specjalna) dodatkowo omawiana jest niepełnosprawność wzrokowa, słuchowa czy ruchowa. Jednak jest on realizowany tylko na dwóch uczelniach.

$\mathrm{Na}$ żadnych z przedmiotów realizowanym w ramach tych modułów nie była poruszana problematyka niepełnosprawności rzadkiej, ani też dziecka ze zdiagnozowaną chorobą rzadką.

\section{Bibliografia}

Chrzanowska I. (2015). Pedagogika specjalna. Od tradycji do wspótczesności, Kraków: Wydawnictwo Impuls.

Hulek A. (1992). Świat ludziom niepetnosprawnym, Warszawa: Polskie Towarzystwo Walki z Kalectwem.

Komisja Wspólnot Europejskich (2008). Komunikat Komisji Do Parlamentu Europejskiego, Rady, Europejskiego Komitetu Ekonomiczno-Spotecznego oraz Komitetu Regionów na temat: Rzadkie choroby: wyzwania stojace przed Europa, Bruksela.

Kubinowski D. (2011). Jakościowe badania pedagogiczne. Filozofia-Metodyka-Ewaluacja, Lublin: Wydawnictwo UMCS.

Kulik M., Wiącek G. (2010). Orzecznictwo w przypadku osób z rzadkimi i sprzężonymi rodzajami niepetnosprawności - porównanie, [w]: A.I. Brzezińska, R. Kaczan, K. Smoczyńska (red.), Sytuacja i możliwości pomocy dla osób z rzadkimi i sprzężonymi ograniczeniami sprawności, Warszawa: Wydawnictwo Naukowe Scholar, s. 89-105.

Matejczuk J. (2010). Potrzeby osób z rzadkimi ograniczeniami sprawności a koncepcja dziatań $w$ ramach programów pomocowych, [w]: A.I. Brzezińska, R. Kaczan, K. Smoczyńska (red.), Sytuacja i możliwości pomocy dla osób z rzadkimi i sprzężonymi ograniczeniami sprawności, Warszawa: Wydawnictwo Naukowe Scholar, s. 106-119.

Matejczuk J. (2010). Btędne koto niepetnosprawności rzadkich: identyfikacja systemowych i podmiotowych problemów osób z rzadkimi ograniczeniami sprawności. „Polityka Społeczna”. Numer specjalny: „Diagnoza potrzeb i podstawy interwencji społecznych na rzecz osób z ograniczeniami sprawności”, nr 1, s. 13-16.

Rozporządzenie Ministra Nauki i Szkolnictwa Wyższego z dnia 25 lipca 2019 r. w sprawie standardu kształcenia przygotowującego do wykonywania zawodu nauczyciela, Dz.U. 2019, poz. 1450 .

Sangiorgi L., Mordenti M. (2017). Diseases Registry: a tool for European Cross-Border Medicine, [w]: G. Rinaldi (red.), New Perspectives in Medical Records. Meeting the Needs of Patients and Practitioners, Switzerland: Springer, s. 141-152. 
Urbańska J. (2010). Zasady rehabilitacji wobec potrzeb osób z rzadkimi i sprzężonymi ograniczeniami sprawności, [w]: A.I. Brzezińska, R. Kaczan, K. Smoczyńska (red.), Sytuacja i możliwości pomocy dla osób z rzadkimi i sprzężonymi ograniczeniami sprawności, Warszawa: Wydawnictwo Naukowe Scholar, s. 120-142.

Wiszejko-Wierzbicka D., Przybylski Ł., Blaszak M. (2010). Europejska sieć informacyjna Orphanet: wyzwanie dla organizacji pozarządowych, [w]: A.I. Brzezińska, R. Kaczan, K. Smoczyńska (red.), Sytuacja i możliwości pomocy dla osób z rzadkimi i sprzężonymi ograniczeniami sprawności, Warszawa: Wydawnictwo Naukowe Scholar, s. 197-207.

\section{ADRES DO KORESPONDENCJI}

Agnieszka Kamyk-Wawryszuk

Uniwersytet Kazimierza Wielkiego w Bydgoszczy

e-mail: a.kamwaw@ukw.edu.pl 